
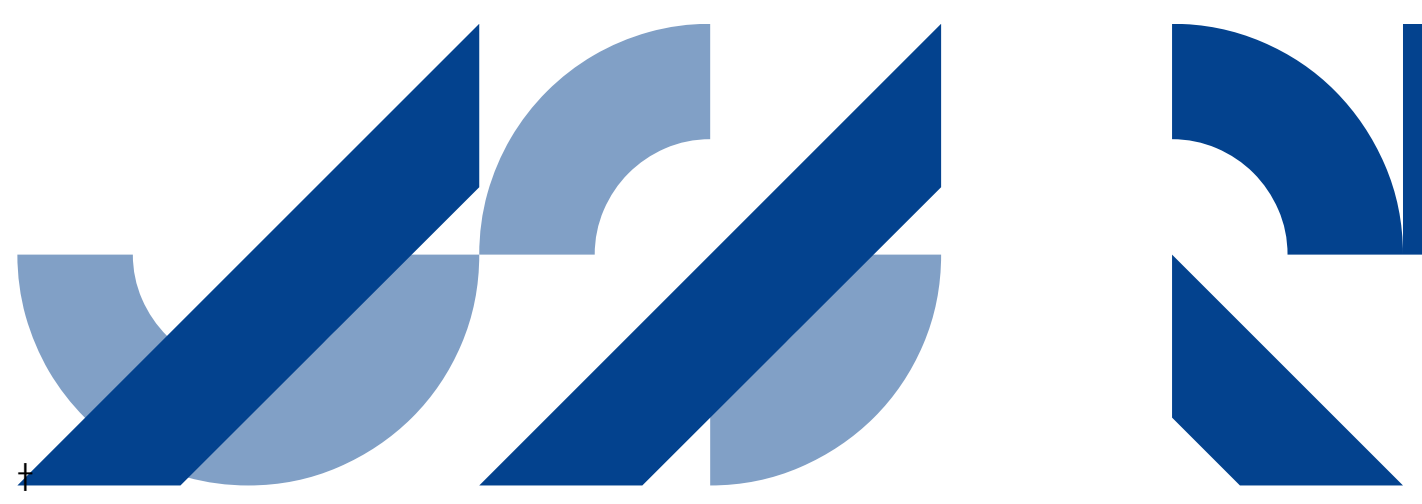

\title{
Placing knowledge:
}

mobility in internationalised

higher education

Paper for SRHE 2014

Hanne Kirstine Adriansen, Karen Valentin \& Gritt B. Nielsen 
Title:

Placing knowledge: mobility in internationalised higher education

Authors:

Hanne Kirstine Adriansen, PhD (geography), Associate Professor

Karen Valentin, PhD (anthropology), Associate Professor

Gritt B. Nielsen, PhD (anthropology), Associate Professor

Department of Education

Aarhus University

Tuborgvej 164

2400 Copenhagen NV

Denmark

www.dpu.dk

DOI: $10.7146 /$ aul. 107.99

(C) 2014 The authors 
Hanne Kirstine Adriansen, Karen Valentin \& Gritt B. Nielsen

Aarhus University, Department of Education, Denmark

Research Domain: International contexts and perspectives (ICP)

Paper for SRHE 2014

\title{
Placing knowledge: mobility in internationalised higher education
}

\begin{abstract}
Internationalisation of higher education is premised by a seeming paradox: On the one hand, academic knowledge strives to be universal in the sense that it claims to produce generalizable, valid and reliable knowledge that can be used, critiqued, and redeveloped by academics from all over the world; on the other hand, the rationale for strengthening mobility through internationalisation is based on an imagination of the potentials of particular locations (academic institutions). Intrigued by this tension between universality and particularity in academic knowledge production, this paper presents preliminary findings from a project that study internationalisation of higher education as an agent in the interrelated processes of place-making and knowledge-making. The project is based on three case-studies. In this paper, focus is on PhD students' change of research environment. This is used as a case for studying what comes to count as e.g. relevant, good, true knowledge, to whom, where and why.
\end{abstract}

\section{Background}

This paper presents preliminary findings from a project concerning the role of mobility in internationalisation of higher education. The project is based on three case-studies one of which is presented here - namely PhD-students' change of research environment.

Since the 1990s, the political and institutional concern with internationalisation of higher education has been accompanied by a substantial growth in research on internationalisation which is dominated by pragmatic publications targeting practitioners and policy-makers in higher education (Teichler, 2005, Kehm 2011). In general, scholarly debates have focused on the role of neo-liberalism as a structuring force in contemporary international education and, 
linked to this, issues of competitiveness, marketization and export of higher education (Brown, Lauder \& Ashton 2008, Mosneaga \& Agergaard 2012) as well as the emergence of an economic (rather than purely academic or social/cultural) rationale for internationalising higher education (de Wit, 1999, 2002; Knight, 2008; Knight \& de Wit, 1999). In terms of mobility of academic staff and students, special attention has been given to students/staff's motivations for going abroad (Allen 2010; Brooks \& Waters, 2011; Findlay et al., 2012; Gonzalez et al., 2011; Jöns 2011), the challenges and benefits of intercultural teaching and learning (Anderson et al. 2006; Huttlinger \& Keating 1991; Kim 2009; Tange \& Jensen 2013), language acquisition (Allen 2010; Balá \& Williams 2004), questions of brain drain/gain/circulation and 'vertical mobility' (Findlay et al. 2006; Hazen \& Alberts 2006; Jöns 2009; Rizvi 2005a), issues of employability, transitions to both low-skilled and high-skilled labour markets (e.g. Brooks \& Waters 2011, Liu-Farrer 2009, Sykes 2012), and aspects of identity formation, sense of belonging and (national, regional, global) citizenship (Ong 2005; Olds \& Thrift 2005, Prazeres 2013, Rizvi 2005b).

\section{Theoretical and conceptual inspiration}

With its focus on mobility, this project is informed by and extends current debates within the field of mobility studies. Addressing various flows of people, technologies, material objects and information, the 'new mobilities paradigm' (Sheller \& Urry 2006) criticises the sedentarist and static bias characterizing much social science. The paradigm demonstrates the significance of movement and networks of connection as well as the interdependent immobile infrastructures within which such mobilities are embedded. Through three cases (one of which is presented here), this project picks up on these discussions and recognizes movement and stasis as fundamentally interconnected aspects of human condition (Schiller \& Salazar 2013). The project takes recent studies of the spatial differentiation and unevenness of international student mobility (Waters \& Brooks 2011, Valentin 2012) one step further by exploring how mobility contributes to reshaping ideas of specific places as competing sites of knowledge production.

When conceived of as situated (Haraway 1988), the production of academic knowledge cannot be seen in isolation from where it is produced (Livingstone 2010); or expressed differently, knowledge is from 'somewhere' (Gupta \& Ferguson 1997). Based on an understanding of internationalisation as human mobility, the project analyses how, in, and through these processes of mobility, places (e.g. a laboratory, an institution, a city, a nation-state or region) 
are conjured up as unique and come to count as central to the production of certain kinds of knowledge. Analytically, the project employs a notion of place as dynamic, best thought of as relational (Agnew, 2011) and requiring human agency (Sack, 1997). Thus place should not be seen as a geographically fixed site, but as a location that is "constructed out of a particular constellation of social relations, meeting and weaving together at a particular locus" (Massey, 1991: 27). In focusing on three cases, the project examines how knowledge-making is intrinsically linked to place-making, i.e. how what comes to count as e.g. relevant, good, universal/particular knowledge, to whom, where and why, is linked to the way people engaged in international collaboration or exchange come to map the world and conjure up particular places.

Case: Changing research environment to construct universal knowledge? This subproject explores the role of mobility for knowledge-making and place-making using Danish PhD-students' change of research environment as an example of mobility. According to the Ministerial Order for the PhD education, PhD-students should "participate in active research environments, including stay at other, mainly foreign, research institutions, private research enterprises etc." (Retsinformation, 2013). Each institution (usually the PhD school) has its own interpretation of this, but generally there is a requirement of 'studying abroad'. Hence, there is a strong notion of particular places as important for the training of PhDstudents. Yet, with increasing globalisation of research and communication (e.g. journal articles available on the internet, communication via e-mail or Skype) and with the idea of scientific knowledge as universal, one may ask why this change of research site is perceived as important.

Building on Livingstone's framework for the geography of scientific knowledge (2010), this case explores how 'knowledge' and 'place' are perceived and reshaped in the context of PhDstudents' mobility. The case examines what comes to count as e.g. relevant, good, true knowledge, to whom, where and why and how these mobility practices remap the world. More specifically the case examines: 1) How do PhD-students and their supervisors articulate rationales for universal knowledge-making and put them into practice against the requirement for change of research environment? 2) How do PhD-students and their supervisors contribute to place-making and remapping the world through their discourses and mobility practices in regard to change of research environment? 


\section{Implications for further research}

While the existing literature clearly addresses the aspect of mobility/immobility, it does not explore and theorise 'place' (see also Prazeres 2013), including how conceptions of place are tightly related to the way people come to understand and value certain kinds of knowledge as universal/particular, and as good or relevant. By emphasising the interconnected aspects of place-making and knowledge-making in processes of internationalisation, this project contributes to and extends the emerging field of geography of knowledge and education (Jöns 2007; Kraftl 2013; Livingstone 2010; Thiem 2009) along with the scholarship linked to the spatial turn in educational research (Fenwick, Edwards, \& Sawchuk 2011; Gulson \& Symes 2007; Helfenbein \& Taylor 2009).

\section{References}

Agnew, J. (2011). Space and Place. In J. Agnew and D. Livingstone (eds.) Handbook of Geographical Knowledge, pp. 316-330. London: Sage.

Allen, H. W. (2010) What shapes short-term study abroad experiences? A comparative case study of students' motives and goals. Journal of Studies in International Education 14, pp.452470

Anderson, P., Lawton, L., Rexeisen, R. J. and Hubbard, A. C. (2006) Short-term study abroad and intercultural sensitivity: a pilot study. International Journal of Intercultural Relations 30, pp 457-469

Balá, V. and Williams, A. M. (2004) 'Been there, done that': international student migration and human capital transfers from the UK to Slovakia. Population, Space and Place 10, 99. 217237.

Brown, P., H. Lauder and D. Ashton (2008). Towards a high-skills economy. Higher education and the new realities of global capitalism. World Yearbook of Education 2008. Geographies of Knowledge, Geometries of Power: Framing the Future of Higher Education. D. Epstein, R. Boden, R. Deem, F. Rizvi and S. Wright.(eds) New York and London, Routledge: 190-210.

Brooks, R. \& J. Waters (2011) Student Mobilities, Migration and the Internationalization of Higher Education. Basingstoke: Palgrave MacMillan

de Wit, H. (1999). Changing Rationales for the Internationalization of Higher Education. International Higher Education, 15, 2-3.

Fenwick, T., Edwards, R., \& Sawchuk, P. (2011). Emerging approaches to educational research: Tracing the socio-material. Routledge.

Findlay, A. M., King, R., Smith, F., Geddes, A. and Skeldon, R. (2012) World Class? An investigation of globalisation, difference and international student mobility. Transacation of the institute of British Geographers 37 (1), pp. 118-131 
Findlay, A. M., King, R., Stam, A. and Ruiz-Gelices, E. (2006) Ever reluctant Europeans: the changing geographies of UK students studying and working abroad. European Urban and Regional Studies 13, pp. 291-318

Gonzalez, C. R., Mesanza, R. B. and Mariel, P. (2011) The determinants of international student mobility flows: an empirical study on the Erasmus programme. Higher Education 63: 412-430.

Gulson K; Symes C, (eds.) (2007). Spatial Theories of Education: Policy and Geography Matters. Routledge, New York.

Gupta, A., \& Ferguson, J. (Eds.). (1997). Anthropological locations: Boundaries and grounds of a field science. University of California Press.

Haraway, D. (1988). Situated knowledges: The science question in feminism and the privilege of partial perspective. Feminist studies 575-599.

Hazen, H. D. and Alberts, H. C. (2006) Visitors or immigrants? International students in the United States. Population, Space and Place 12, pp. 201-216

Helfenbein, R. and Taylor, I. H. 2009. Critical geographies of education: Introduction. Educational Studies 45: 236-239.

Huttlinger, K. and Keating, S. B. (1991) Understanding cultural diversity through a student exchange program Nurse Educator 16 (5): 29-33

Jöns, H. (2007). Transnational mobility and the spaces of knowledge production: a comparison of global patterns, motivations and collaborations in different academic fields. Social Geography, 2(2), 97-114.

Jöns, H. (2009), Brain Circulation and transnational knowledge networks: studying long-term effects of academic mobility to Germany, 1954-2000. Global Networks, 9(3), pp. 315-338

Jöns, H. (2011) Transnational academic mobility and gender, Globalisation, Societies and Education, 9 (2), pp. 183-209

Kehm, B. M. (2011) Research on Internationalisation in Higher Education. International HE congress. Retrieved from: http://www.uyk2011.org/kitap/pages/uyk2011 s 0231 0239.pdf

Kim, T. (2009) Shifting patterns of transnational academic mobility: a comparative and historical approach. Comparative Education, vol. 45(3): 387-403.

Knight, J. (2008). The internationalization of Higher Education: Complexities and Realities. In D. Teferra \& J. Knight (Eds.), Higher Education in Africa: The International Dimension (pp. 1-43). Accra/Boston: AAU/CIHE.

Knight, J., \& de Wit, H. (Eds.). (1999). Quality and internationalization in higher education. Paris: Organization for Economic Cooperation and Development. 
Kraftl, P. 2013. Geographies of Alternative Education: Diverse Learning Spaces for Children and Young People. The Policy Press, Bristol.

Liu-Farrer, G. (2009) Educationally Channeled International Labor Mobility: Contemporary Student Migration from China to Japan. International Migration Review, 43(1):178-2004

Livingstone, D. N. (2010). Putting science in its place: geographies of scientific knowledge. University of Chicago Press.

Massey, D. (1991). A global sense of place. Marxism today, 35(6):24-29.

Mosneaga, Ana \& Jytte Agergaard (2012) Agents of internationalisation? Danish universities' practices for attracting international students. Globalisation, Societies and Education, 10(4):519-538

Olds, K.and N. Thrift (2005). Cultures on the Brink: Reengineering the Soul of Capitalism - On a Global Scale. In Global Assemblages: Technology, Politics, and Ethics as Anthropological Problems. Aihwa Ong and Stephen J. Collier,. Eds. Pp. 270-290. Malden, MA: Blackwell

Ong, A. (2005). Ecologies of Expertise: Assembling Flows, Managing Citizenship. Global Assemblages. Technology, Politics, and Ethics as Anthropological Problems. A. Ong and S. J. Collier. Malden, Oxford and Carlton, Blackwell Publishing: 337-354.

Prazeres, L. (2013) International and Intra-national Student Mobility: Trends, Motivations and Identity. Geography Compass 7(11): 804-820

Retsinformation (2013) Bekendtgørelse om ph.d.-uddannelsen ved universiteterne og visse kunstneriske uddannelsesinstitutioner (ph.d.-bekendtgørelsen) https://www.retsinformation.dk/Forms/R0710.aspx?id=152430

Rizvi, F (2005a) Rethinking Brain Drain in the Era of Globalisation. Asia Pacific Journal of education, 25 (2): 175-192

Rizvi, F. (2005b) International education and the production of cosmopolitan identities. Research Institute for Higher Education. RIHE International publication Series, pp. 77-92 Sack, R. D. (1997) Homo Geographicus. Baltimore: Johns Hopkins University Press. Schiller, N.G. \& N. Salazar (2013) Regimes of Mobility across the Globe. Journal of Ethnic and Migration Studies, 39(2):183-200.

Sheller, M. and J. Urry (2006) The new mobilities paradigm. Education and Planning A, 38:207226

Sykes, B. with E.N. Chaoimh (2012) Mobile Talent? The Staying Intentions of International Students in Five EU Countries. Berlin: Sachverständigenrat deutscher Stiftungen für Integration und Migration. 
Tange, H. \& I. Jensen (2012) Good teachers and deviant learners? The meeting of practices in university level education. Journal of Research in International Education, 11(2):181-193.

Teichler, U. (2005) Research on Higher Education in Europe. In. European Journal of Education,40(4), 447-469.

Thiem, C. H. (2009). Thinking through education: the geographies of contemporary educational restructuring. Progress in Human Geography, 33(2), 154-173.

Valentin, K. (2012) Caught between internationalisation and immigration. The case of Nepalese students in Denmark. Learning and Teaching, 5(3):56-74. 